\title{
Neonatal screening in Europe; the situation in 2004
}

\section{J. Gerard Loeber}

Published online: 27 April 2008

(C) SSIEM and Springer 2008

Erratum to: J Inherit Metab Dis 2007; 30: 430-438

DOI: $10.1007 / s 10545-007-0644-5$

The name of George Reclos should be replaced by those of Kleopatra Schulpis and Chryssanthi Mengreli in the Acknowledgements of the article, as the scientists responsible for the data of the Greek screening programme.

The online version of the original article can be found at http://dx.doi.org/10.1007/s10545-007-0644-5.

\section{J. G. Loeber}

International Society for Neonatal Screening,

National Institute for Public Health,

Bilthoven, The Netherlands

J. G. Loeber $(\bowtie)$

International Society for Neonatal Screening,

National Institute for Public Health (RIVM),

PO Box 1, 3720 BA BI Bilthoven, The Netherlands

e-mail: Gerard.Loeber@rivm.nl 